\title{
THE POLLUTION INDEX AND CARRYING CAPACITY OF THE UPSTREAM BRANTAS RIVER
}

\author{
Kustamar $^{1}$ and ${ }^{*}$ Lies Kurniawati Wulandari ${ }^{1}$ \\ ${ }^{1}$ Faculty of Civil Engineering and Planning, National Institute of Technology (ITN) Malang, Indonesia \\ *Corresponding Author, Received: 28 July 2019, Revised: 13 Jan. 2020, Accepted: 17 March 2020
}

\begin{abstract}
River is one of the surface water resources that is often polluted by various human activities. With its dynamic characteristics, a river must be periodically examined to determine its water quality. This study aims to investigate the carrying capacity of the Brantas river in East Java, Indonesia. The observation was done by measuring TSS (Total suspended solid), TDS (Total dissolved solid), and oil and grease in the upstream zone of the Brantas river. This research used a descriptive method. The determination of the research stations was based on the condition of the watershed and its surroundings, assuming that there was a decrease in water quality. The sampling points include Pendem Bridge (1), DAM (local water company) Sengkaling (2), Simpang Remujung Bridge (3), and Samaan District (4). The results demonstrated that the upstream Brantas river at each sampling point had different pollution levels. Generally, the sampling point 1 (Pendem Bridge) was the cleanest zone compared to other sampling points. On the other hand, sampling point 4 (Samaan District) was the most polluted site of the upstream zone. Based on the quality standards of class III water (PP No. 82 Year 2001), it was noticeable that the upstream Brantas river was mildly polluted based on the TSS parameter. However, it was not polluted when referring to the TDS parameter and heavily polluted based on the oil and grease parameter. Regarding the carrying capacity, the upstream Brantas river at the sampling point 4 (Samaan District) has exceeded the capacity of the river for self-purification.
\end{abstract}

Keywords: Pollution, Organic waste, Brantas river.

\section{INTRODUCTION}

Water quality is an important aspect that must be considered in sustainable regional development [1]. One of the main resources of water is river. The river is a meeting point of water from various sources, either from rainwater, springs and even wastewater from human activities such as agriculture, transportation facilities, industry, urban areas, and settlements. Nowadays, there is still a thought in the community that the river is an ideal site for waste disposal from almost every antrophogenic activities as the river is the catchment area with its continuously flowing water. In East Java, Indonesia, there lies the longest river in the province, namely the Brantas River. Brantas River has a length of $\pm 320 \mathrm{~km}$ and a drainage area of $\pm 12,000 \mathrm{~km} 2$, or covering approximately a quarter of the total area of East Java province. Brantas River flows from the slopes of Mount Arjuna and Anjasmara in Malang Regency, passing Blitar Regency, Tulungagung, Kediri, Nganjuk, Jombang, Mojokerto until Pasuruan Regency (Porong River) and Surabaya City (Kalimas River).

Nowadays, water pollution is becoming an environmental issue everywhere, not only in the ocean but also in rivers and lakes that are closely related to daily life [2]. Water pollution is the contamination of pollutants into the water which results in a decrease in water quality so that it can disturb the environment and endanger public health. According to Law Number 32 of 2009 (UUPPLH), environmental pollution is the entry of living things, substances, energy and or other components into the environment from human activities so that it exceeds the specified quality standards [3].

The increasing demand of water and the regional development accompanied by the establishment of new industrial zones cause the more intense and complex problem in water resources quality. Previous studies reported that the upstream Brantas river was experiencing 2 main problems, which were the decrease of water quality [4] and the deterioration of the surrounding vegetation [5] that even worsen the problem. Progress in the industrial sector itself has an impact toward the quality of the natural resources, including water, that can harm humans [6]. The intensive use of water for the consumption, sanitation, industrial and other purposes can decrease the quantity and quality of the water resources. This degradation is inevitable. Therefore, the periodical analysis of the water quality is an important work to do. The report of the water quality analysis can be used as a consideration and recommendation for the responsible stakeholders and the community to overcome the problem simultaneously.

Water quality can be determined by observing physical parameters, such as temperature, dissolved 
solids, and suspended solids, as well as chemical parameters such as $\mathrm{pH}$, TSS, TDS, oil and grease content, and other parameters [7]. In addition, it can be arranged the number of pollutants that may be discharged into the river based on scientific studies on the capacity of the river against pollutant load. This is done to ensure that waste discharged into the river does not exceed the ability of river water to remediate itself. Pollution can be grouped into point sources and non-point sources. The point source is a place that is a source of pollution that is known with certainty such as industrial activities, while the non-point source is pollution from large areas such as agriculture and settlements that are not available Wastewater Treatment Plants (WWTP).

The ability of water to clean itself naturally from various contaminants and pollutants is known as self-purification. Furthermore, the capacity of the pollution load is the ability of water in a water source to receive waste input without causing the water to become polluted. Pollution burden is the amount of a pollutant contained in water or waste [8]. The parameters used to calculate the capacity of the pollution load and which affect the ability of river water for self-purification include discharge, flow velocity, total pollutant load, temperature, weather, shape of the stream, channel or river dimensions and dissolved oxygen [7]. Therefore, it is necessary to determine the carrying capacity of the upstream Brantas river water based on methods that have been tested scientifically, such as the Mass Balance method and the Pollution Index Method. By investigating the water quality of the longest river in East Java, this study presents an important report of the current condition of the upstream Brantas River that can be used as a consideration by the local government and the community to work together for the conservation of the Brantas River, especially in the upstream zone.

\section{METHOD}

This study used descriptive method to report the carrying capacity of the upstream Brantas River toward pollution that was mainly represented by the suspended and dissolved solids, and the oil and grease parameters. The focus of observation was on the water quality parameters including water temperature, pH, TSS (Total Suspended Solid), TDS (Total Dissolved Solid), and oil and grease level. The study was carried out in the upstream zone of Brantas River, specifically at four sampling points, including Pendem Bridge as sampling point 1, DAM (local water company) Sengkaling as sampling point 2, Simpang Remujung Bridge as sampling point 3, and Samaan District as sampling point 4 . The determination of sampling points was using the principle purposive sampling method in which the researchers consider the main sites of the pollution in the area or upstream Brantas river. Water samples were taken in the morning (08.0011.00 AM). The sampling method refers to the sampling technique following the width and depth of the river, which is the grab sampling method. Primary data was obtained by measuring river water samples from each sampling point. The procedure of water quality measurement was based on the standard procedures in the Environmental Laboratory, the National Institute of Technology, Malang. Furthrmore, the pollution load capacity was calculated using the Mass Balance method [9] with the following calculation:

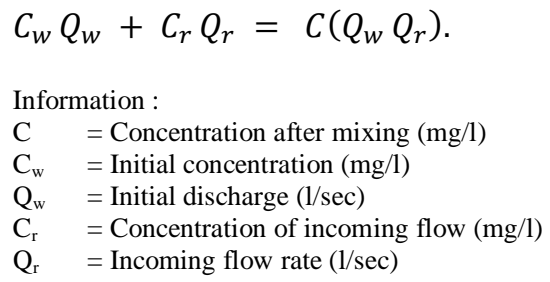

Mathematical models that use mass balance calculations can be implemented to determine the average concentration of the river water both from the point and non-point sources. This calculation can also be used to determine the percentage of the change in flow rate or pollution load or the carrying capacity. The amount of pollution based on each parameter is compared to the quality standards of class III water according to the Government Regulation of the Republic of Indonesia Number 82 year 2001 (PP No.82 Tahun 2001). Class III is the category for water that can be used for agricultural purposes.

\section{RESULT AND DISCUSSION}

\subsection{Water Quality Anaysis}

The data of water quality of the Upstream Brantas river at each sampling point are shown in Table 1. Sampling point 1 is the Pendem Bridge, sampling point 2 is DAM Sengkaling, sampling point 3 is Simpang Remujung Bridge, and sampling point 4 is Samaan District. Pendem Bridge is the first sampling point closest to the water sources, while the Samaan District is last the sampling point located in the middle of the urban community in Malang City. Each sampling point has its own characteristics, and each characteristic contributes to the condition and the quality of river water. Water temperature and $\mathrm{pH}$ are the basic parameters to measure for knowing the common characteristic of the river. The main focus of the discussion is about the suspended and dissolved solids, as well as the oil and grease parameter. 
Table 1 Water Quality of Upstream Brantas River

\begin{tabular}{|c|c|c|c|c|c|c|c|c|c|c|c|}
\hline \multirow{3}{*}{ No. } & \multirow{3}{*}{$\begin{array}{l}\text { Sampling } \\
\text { Point }\end{array}$} & \multirow{2}{*}{\multicolumn{2}{|c|}{$\begin{array}{c}\text { Temperature }\left({ }^{\circ} \mathrm{C}\right) \\
\text { Repetition }\end{array}$}} & \multicolumn{2}{|c|}{$\mathrm{pH}$} & \multicolumn{2}{|c|}{ TSS (mg/L) } & \multicolumn{2}{|c|}{ TDS (mg/L) } & \multicolumn{2}{|c|}{$\begin{array}{c}\text { Oil \& Grease } \\
(\mathrm{mg} / \mathrm{L})\end{array}$} \\
\hline & & & & & & & & & tion & & ition \\
\hline & & $\mathrm{I}$ & II & $\mathrm{I}$ & II & I & II & I & II & I & II \\
\hline 1 & $\begin{array}{l}\text { Pendem } \\
\text { Bridge }\end{array}$ & 21.2 & 21.4 & 7.8 & 6.3 & 10 & 10 & 129.4 & 128.8 & 400 & 500 \\
\hline 2 & $\begin{array}{c}\text { DAM } \\
\text { Sengkaling } \\
\text { Simpang }\end{array}$ & 22.3 & 22.1 & 7.2 & 7 & 30 & 20 & 143.2 & 142.7 & 500 & 500 \\
\hline 3 & $\begin{array}{l}\text { Remujung } \\
\text { Bridge }\end{array}$ & 23.1 & 23.2 & 6.2 & 5.1 & 40 & 30 & 147.9 & 146.5 & 700 & 900 \\
\hline 4 & $\begin{array}{l}\text { Samaan } \\
\text { District }\end{array}$ & 24.6 & 24.5 & 5.1 & 5 & 70 & 50 & 148.4 & 148.2 & 2.200 & 2.000 \\
\hline
\end{tabular}

The results of water quality analysis show that the overall water temperature was normal. Then, the $\mathrm{pH}$ of river water at the sampling points 1,2 and 3 are still within the allowed range of class 2 and class 3 water, which is between 6-9. Meanwhile, the $\mathrm{pH}$ at the sampling point 4 (Samaan District) has a substandard level, or too acidic. A good $\mathrm{pH}$ level is at a level that supports biological life in water (neutral $\mathrm{pH}=7$ ). Water with low $\mathrm{pH}$ (acid) is characterized by colored water and covered with aquatic plants. In addition, low $\mathrm{pH}$ level also makes water corrosive. Alkaline water (high $\mathrm{pH}$ ) generally contains high dissolved solids. This condition can affect water sources that are used by residents, especially groundwater obtained from wells, both dug wells and drilled wells [10]. The infiltration process makes the quality of well water can also be polluted due to the condition of the surrounding water that is polluted from various human activities.

Based the TSS parameter, the highest level was found at the sampling point 4 (Samaan District), which was $70 \mathrm{mg} / \mathrm{L}$, while the lowest TSS level was found at the sampling point 1 (Pendem Bridge) with a level of $10 \mathrm{mg} / \mathrm{L}$. Compared to the results of Mahyudin and Tri's research conducted at the Metro River, which is also located in Malang, the TSS levels were ranging from 40 to $78 \mathrm{mg} / \mathrm{l}$ [11]. Thus, it can be stated that the pollution based on TSS parameters in rivers in Malang are relatively at the same level. Furthermore, the highest TDS level was found at the sampling point 4 (Samaan District) with $148.4 \mathrm{mg} / \mathrm{L}$, while the lowest level was at the sampling point 1 (Pendem Bridge) with a level of $128.8 \mathrm{mg} / \mathrm{L}$. According to Wulandari, the TDS parameter represents the dissolved solids, which are parameters that describe the concentration of cation and anions contained in water. The main sources of TDS in waters are generally from agricultural, domestic and industrial activities [12]. In this study, it is suspected that the source of TDS in the upstream Brantas River not only came from agricultural waste but also domestic waste from surrounding communities.

Regarding the oil and grease level, sampling point 4 (Samaan District) had the highest level (2200 mg/L) and sampling point 1 (Pendem Bridge) had the lowest level (400 mg/L). Research conducted by Supenah et al. at the Condong River in Cirebon also showed a high level of oil and grease $(8.50$ - $14.67 \mathrm{mg} / \mathrm{l})$ which polluted the water due to input from the factory waste [13]. However, the measurement results in the Brantas river obtained from this study are even higher, even though the presence of factories is not as many as in Cirebon. Therefore, it can be concluded that the input of oil and grease pollutants comes mostly from domestic waste. This is a serious issue because the Brantas river observed is an upstream area. Rivers are natural flowing resources so that the use of water in the upstream will eliminate opportunities in the downstream. In other words, pollution in the upstream will affect the water quality of the downstream, thus the preservation and conservation of the river must be started from the upstream zone [14].

The excess oil and grease content in the waters will reduce the penetration of sunlight and the diffusion of oxygen into the water which will ultimately inhibit the ability of self-purification [15]. Furthermore, the lack of photosynthesis rate and $\mathrm{O} 2$ input from the air will disrupt the organisms in the water. Oil and grease are organic materials that have long and complex carbon chains. Some oil and grease emulsions will degrade through spontaneous photooxidation and oxidation by microorganisms. The decomposition of fats and oils under the lack of oxygen will cause an incomplete decomposition, causing a rancid odor. Some of the components that make up the oil are also known to be toxic to animals and humans, depending on their structure and molecular weight [16].

\subsection{Carrying Capacity of the Upstream Brantas River}

The carrying capacity of a river represents the maximum load of pollutions that can be Generally, the results of the analysis using the Mass Balance method show that the water quality of the Brantas river was not in accordance with class III standards, especially for the sampling point 4 (Samaan District). Tables 2 to 4 display the data from the calculation of water quality and the carrying capacity of the Brantas river toward pollutions. 
Table 2 River's Carrying Capacity toward TSS

\begin{tabular}{llcccccc}
\hline No. & Sampling Point & $\begin{array}{c}\text { Discharge } \\
\text { (L/day) }\end{array}$ & $\begin{array}{c}\text { TSS } \\
(\mathrm{mg} / \mathrm{L})\end{array}$ & $\begin{array}{c}\text { Pollution } \\
\text { Load } \\
\text { (mg/day) }\end{array}$ & $\begin{array}{c}\text { Class 3 } \\
\text { Standard }\end{array}$ & $\begin{array}{c}\text { Maximum } \\
\text { Load } \\
\text { (mg/day) }\end{array}$ & $\begin{array}{c}\text { Carrying } \\
\text { Capacity } \\
\text { (mg/day) }\end{array}$ \\
\hline 1 & Pendem Bridge & 166,23 & 40 & $6.649,19$ & 400 & $66.491,87$ & $59.842,69$ \\
2 & DAM Sengkaling & 97,50 & 25 & $2.437,44$ & 400 & $38.998,97$ & $36.561,54$ \\
3 & Simpang Bridge & 134,16 & 50 & $6.708,17$ & 400 & $53.665,37$ & $46.957,20$ \\
4 & Samaan Bridge & 106,04 & 60 & $6.362,44$ & 400 & $42.416,30$ & $36.053,85$ \\
\hline
\end{tabular}

Table 3 River’s Carrying Capacity toward TDS

\begin{tabular}{llcccccr}
\hline No. & Sampling Point & $\begin{array}{c}\text { Discharge } \\
\text { (L/day) }\end{array}$ & $\begin{array}{c}\text { TDS } \\
(\mathrm{mg} / \mathrm{L})\end{array}$ & $\begin{array}{c}\text { Pollution } \\
\text { Load } \\
(\mathrm{mg} / \text { day })\end{array}$ & $\begin{array}{c}\text { Class 3 } \\
\text { Standard }\end{array}$ & $\begin{array}{c}\text { Maximum } \\
\text { Load } \\
\text { (mg/day) }\end{array}$ & $\begin{array}{c}\text { Carrying } \\
\text { Capacity } \\
\text { (mg/day) }\end{array}$ \\
\hline 1 & Pendem Bridge & 166,23 & 900 & $149.606,71$ & 1000 & $166.229,68$ & $16.622,97$ \\
2 & DAM Sengkaling & 97,50 & 700 & $68.248,20$ & 1000 & $97.497,43$ & $29.249,23$ \\
3 & Simpang Bridge & 134,16 & 1.000 & $134.163,44$ & 1000 & $134.163,44$ & 0,00 \\
4 & Samaan Bridge & 106,04 & 1.100 & $116.644,81$ & 1000 & $106.040,74$ & $10.604,07$ \\
\hline
\end{tabular}

Table 4 River’s Carrying Capacity toward Oil and Grease

\begin{tabular}{clcccccc}
\hline No. & Sampling Point & $\begin{array}{c}\text { Discharge } \\
\text { (L/day) }\end{array}$ & $\begin{array}{c}\text { Oil \& } \\
\text { Grease } \\
(\mathrm{mg} / \mathrm{L})\end{array}$ & $\begin{array}{c}\text { Pollution } \\
\text { Load } \\
\text { (mg/day) }\end{array}$ & $\begin{array}{c}\text { Class 3 } \\
\text { Standard }\end{array}$ & $\begin{array}{c}\text { Maximum } \\
\text { Load } \\
\text { (mg/day) }\end{array}$ & $\begin{array}{c}\text { Carrying } \\
\text { Capacity } \\
\text { (mg/day) }\end{array}$ \\
\hline 1 & Pendem Bridge & 160,29 & 400 & $64.117,16$ & 1000 & $160.292,91$ & $96.175,75$ \\
2 & DAM Sengkaling & 97,50 & 500 & $48.748,72$ & 1000 & $97.497,43$ & $48.748,72$ \\
3 & Simpang Bridge & 127,67 & 950 & $121.288,07$ & 1000 & $127.671,66$ & $6.383,58$ \\
4 & Samaan Bridge & 97,35 & 2.200 & $214.167,53$ & 1000 & $97.348,88$ & $116.818,65$ \\
\hline
\end{tabular}

Water discharge is related to the level of water pollution. According to Yudo and Nusa, water that has a low input discharge tends to be more polluted compared to bodies of water that have a larger discharge. This is caused by the principle of dilution [17]. Based on the calculation results, the results of the analysis show that the input of suspended solids (TSS) at all stations does not exceed the carrying capacity. Calculation results, especially at the sampling point 4 (Samaan District), show that the carrying capacity was $36,053.85 \mathrm{mg} /$ day, while the daily pollution load was $6,362.44 \mathrm{mg} /$ day and the maximum pollution load was $42,416.30 \mathrm{mg} /$ day. In addition, the TDS parameter at the sampling point 4 (Samaan District) has exceeded the carrying capacity. The calculation results demonstrate the capacity of $10604.07 \mathrm{mg} /$ day, while the daily pollution load is $116644.81 \mathrm{mg} /$ day, with a maximum pollution load of $106040.74 \mathrm{mg} /$ day.

Furthermore, the input of oil and grease pollution at Station 4 (Samaan District) has exceeded the carrying capacity. The calculation results show the number $116818.65 \mathrm{mg} /$ day, while the daily pollution load was $214167.53 \mathrm{mg} /$ day and the maximum pollution load was $97348.88 \mathrm{mg} / \mathrm{day}$. Oils and grease are members of the lipid group. Oils and grease contain complex lipids, namely lecithin, cephalin, phosphatide and glycolipids and sterols which are free or bound to fatty acids, free fatty acids, waxes, fat-soluble pigments, and hydrocarbons. Oils and fats consist of mixed triglycerides such as esters of glycerol and longchain fatty acids [18,19]. Oil and grease is the parameter that causes water pollution, thus the concentration must be limited. Oil has a light density, which is lighter than water, therefore it will form a thin layer on the surface of the water [20].

\subsection{Pollution Index}

To determine the pollution index (IP) of the upstream Brantas river, this study compared the result of the analysis with the Decree of the Minister of Environment Republic of Indonesia Number 115 year 2003 (Kepmen LH No.115 Tahun 2003). The basis for determining whether or not the river is polluted is the criteria of class 3 water. The index is briefly explained as follows:

$\begin{array}{ll}0 \leq \mathrm{IP} \leq 1 & \text { : Meets quality standards (clean) } \\ 1 \leq \mathrm{IP} \leq 5 & \text { : Mildly polluted } \\ 5<\mathrm{IP} \leq 10 & \text { : Moderately polluted } \\ \text { IP }>10 & \text { : Heavily polluted } \\ \text { The results } & \text { of the pollution index analysis at }\end{array}$ each sampling point are explained in tables 5 to 7 . 
Table 5 Pollution Index Based on TSS Level

\begin{tabular}{clcc}
\hline \multirow{2}{*}{ No } & \multirow{2}{*}{ Sampling Point } & & Pollution Index \\
\cline { 3 - 4 } & & PI Value & Pollution Category \\
\hline 1 & Pendem Bridge & 4,148 & Mildly Polluted \\
2 & DAM Sengkaling & 4,026 & Mildly Polluted \\
3 & Simpang Bridge & 3,515 & Mildly Polluted \\
4 & Samaan & 2,866 & Mildly Polluted \\
\hline
\end{tabular}

Table 6 Pollution Index Based on TDS Level

\begin{tabular}{clcc}
\hline \multirow{2}{*}{ No. } & \multirow{2}{*}{ Sampling Point } & & Pollution Index \\
\cline { 3 - 4 } & & PI Value & Pollution Category \\
\hline 1 & Pendem Bridge & 0,946 & Clean \\
2 & DAM Sengkaling & 0,451 & Clean \\
3 & Simpang Bridge & 0,755 & Clean \\
4 & Samaan & 1,158 & Mildly Polluted \\
\hline
\end{tabular}

Table 7 Pollution Index Based on the Oil and Grease Level

\begin{tabular}{clcc}
\hline \multirow{2}{*}{ No } & \multirow{2}{*}{ Sampling Point } & \multicolumn{2}{c}{ Pollution Index } \\
\cline { 3 - 4 } & & PI Value & Pollution Category \\
\hline 1 & Pendem Bridge & 0,630 & Clean \\
2 & DAM Sengkaling & 10,766 & Heavily Polluted \\
3 & Simpang Bridge & 11,250 & Heavily Polluted \\
4 & Samaan & 12,660 & Heavily Polluted \\
\hline
\end{tabular}

The river is polluted if the water quality is not in accordance with its designation [21]. Naturally, river ecosystems have a natural recuperation capacity (self-purification) to assimilate all pollutants that enter the river flow. However, this purification ability also depends on the intensity of pollutants from the surrounding environment. If the input of pollutants from the surrounding environment continues, the self-purification capacity of the river will not be able to offset the rate of pollution load. As a result, the water quality of the river will continue to deteriorate [22].

Based on the TSS parameter (Table 5), the upstream Brantas river at all sampling points has experienced minor pollution. This is allegedly due to erosion that mostly occurs in riverbanks, apart from runoff water from agricultural areas in the City of Batu and surrounding areas. Research by Kustamar et al. reported that the condition of the Brantas River in the Upper Watershed itself is having the issue of vegetation damage, resulting in the high rate of erosion and direct runoff from surrounding areas [5]. Furthermore, based on the TDS parameter (Table 6), it can be seen that sampling points 1, 2 and 3 are not polluted based on the class 3 water standards. Meanwhile, the pollution index of the sampling point 4 (Samaan District) is included in the mildly polluted category. This shows that the input of dissolved solids in the Brantas River in the Samaan District area has exceeded the threshold for class 3 water. In addition, based on the oil and grease parameter (Table 7), sampling point 1 (Pendem Bridge) did not experience pollution, while sampling point 2 (DAM Sengkaling), 3 (Simpang Bridge) and 4 (Samaan District) experienced heavy pollution. All three stations are heavily polluted due to high levels of pollution from human activities around the watershed.

Several human activities that can be the cause of pollution in the upstream Brantas river include household activities (domestic waste), hospitals and factories (industrial waste). The hospital is a health care institution that produces wastewater high of chemicals. If the hospital does not have a good sewage treatment system, then the waste can pollute the river flow. One of the hospitals located in the vicinity of the study area is the Unisma Hospital located in Dinoyo Village, Malang, East Java. The hospital is close to sampling point 3 (the Simpang Remujung bridge). In addition, other main activities that contribute to river pollution are industrial activities, such as ceramics and ice factories. Industrial waste is influential on the pollution level of the river, especially if it is not supported by a good sewage treatment system. This ceramics factory is also located in Kelurahan Dinoyo, Malang City, not far from the Unisma hospital. The ice factory is located in Ketawanggede Village, Malang City, which is also close to the ceramic factory and right next to the river. Based on the regulations, the plant's standing land has violated Law Number 7 of 2004 concerning Water Resources, as well as Government Regulation 
Number 38 of 2011 concerning Rivers. The prior and revised rules emphasize that areas of 10 to 20 meters are the river banks, so the building is not allowed in that area. In other words, rivers, including borders, are state-owned zone. A large number of human activities around the river and the establishment of these factories are the main factors of pollution in the Brantas river.

\section{CONCLUSION}

It can be concluded that the upstream Brantas river at each sampling point has different pollution conditions. Sampling point 1 (Pendem Bridge) is the closest to the water source, so it is relatively less polluted (clean) compared to other sampling points. On the other hand, sampling point 4 (Samaan District) is the most polluted upstream area, because river water has passed through previous watersheds that have received waste input from domestic activities. Based on class III water quality standards (Government Regulation of the Republic of Indonesia Number 82 the Year 2001), it can be concluded that the upstream Brantas river is not polluted when referring to the TDS parameters. However, the river is mildly polluted based on the TSS parameter and heavily polluted based on the oil and grease parameter. Regarding the carrying capacity, the upstream Brantas river at the sampling point 4 (Samaan District) has exceeded the capacity for self-purification.

Therefore, the local government is suggested to provide comprehensive socialization for the community about the importance of protecting the river ecosystem, as well as the regulations when violations occur. Thus, the community will be more aware to participate in maintaining the water quality of the Brantas River. In addition, the local government must take action against several industries that violate regulations related to waste disposal systems and land for the establishment of a factory. The factories in the study area, they must implement a good waste management system, so that the wastewater does not pollute the Brantas river and cause disruption to the river ecosystem and human health. For the future studies, it is suggested to investigate the water quality of Brantas River in the other regions, especially the next zone in Blitar Regency or Tulungagung Regency. In addition, the development of techology and conservation programs to overcome the river pollution is strongly recommended.

\section{REFERENCES}

[1] Cordoba E.B., Martınez A.C., and Ferrer E.V. Water Quality Indicators: Comparison of a Probabilistic Index and a General Quality Index. The Case of the Confederacion Hidrografica del
Jucar (Spain). Ecological Indicators, Vol. 10, 2010, pp. 1049-1054.

[2] Harman, R.H.B. Ash-Shiddiq, and Munawir B. Pratama. Water Quality and Sedimentation Modelling in Singkarak Lake, Western Sumatra. International Journal of GEOMATE, Vol. 16, Issue 54, 2019, pp. 94-102.

[3] Indarsih, W., Slamet Suprayogi, and M. Widyastuti. Water Quality of Bedog River Due to Wastewater Disposal of Batik Industry in Wijirejo Village. Magazine of Geography Indonesia, Vol. 25, Issue 1, 2011, pp. 40-54. (Kajian Kualitas Air Sungai Bedog Akibat Pembuangan Limbah Cair Sentra Industri Batik Desa Wijirejo, Majalah Geografi Indonesia).

[4] Yetti, E., Dedi Soedharma, and Sigid Haryadi. Water Quality of the Rivers in the Upstream Zone of Brantas River in Malang Region Related to the Land Use and Human Activities. IPSL, Vol. 1, Issue 1, 2011, pp.10-15. (Evaluasi Kualitas Air Sungai-Sungai di Kawasan Brantas Hulu Malang dalam Kaitannya dengan Tata Guna Lahan dan Aktivitas Masyarakat di Sekitarnya).

[5] Kustamar, Togi H. Nainggolan, Agung Witjaksono, Addy Utomo, and Lily Montarcih L. Development of the Conservative Village Model in the Upstream Brantas River. International Journal of GEOMATE, Vol. 15, Issue 50, 2018, pp. 182-188.

[6] Ramadhani, Edni. Analysis of Water Pollution in Bengawan Solo River Due to Industrial Waste in Kebakkramat District, Karanganyar Regency. Published Manuscript. Undergraduate Thesis. Faculty of Geography. Muhammadiyah University of Surakarta. 2016. (Analisis Pencemaran Kualitas Air Sungai bengawan Solo Akibat Limbah Industri di Kecamatan Kebakkramat Kabupaten Karanganyar).

[7] President of the Republic of Indonesia. The Management of Water Quality and Water Pollution Control. Government Regulation of the Republic of Indonesia, Number 82 Year 2001. (Pengelolaan Kualitas Air dan Pengendalian Pencemaran Air, Peraturan Pemerintah Republik Indonesia).

[8] Minister of Environment. Guidelines for Determining the Carrying Capacity of Water Sources. Decree of the Minister of the Environment, Number 110 Year 2003. (Pedoman Penetapan Daya Tampung Beban Pencemaran Air Pada Sumber Air. Keputusan Menteri Negara Lingkungan Hidup).

[9] Linsley, R.K., Joseph, B. Franzini, David, L. Freyberg, and George, T. Water Resources Engineering. McGraw-Hill. New York. 1995.

[10] Ningrum, Susanti Oktavia. Water Quality of the Wells Around the Sugar Factory of Rejo Agung Baru, Madiun City. Journal of 
Environmental Health, Vol. 10, Issue 1, 2018, pp. 1-12. (Analisis Kualitas Badan Air dan Kualitas Air Sumur di Sekitar Pabrik Gula Rejo Agung Baru Kota Madiun, Jurnal Kesehatan Lingkungan).

[11] Mahyudin, Soemarno, and Tri Budi Prayogo. Analysis of Water Quality and Pollution Control Strategy of Metro River in Kepanjen City, Malang Regency. J-PAL, Vol. 6, Issue 2, 2015, pp. 105-114. (Analisis Kualitas Air dan Strategi Pengendalian Pencemaran Air Sungai Metro di Kota Kepanjen Kabupaten Malang).

[12] Wulandari, Lies Kurniawati. (2019). Physical Model of the Blackwater Remediation Technology at the Communal Septic Tank. Dreamlitera Publishing. Malang. 2019. (Model Fisik Pengolahan Limbah Blackwater Pada Septictank Komunal).

[13] Supenah, Pipin, Endang Widyastuti, and Rawuh E.P. Water Quality of Condong River Affected by the Wastewater of Batik Trusmi Industry in Cirebon. Biosfera, Vol. 32, Issue 2, 2015, pp. 110-118. (Kajian Kualitas Air Sungai Condong yang terkena Buangan Limbah Cair Industri Batik Trusmi Cirebon).

[14] Azwir. Water Pollution Analysis of Tapung Kiri River affected by the Wastewater of Palm Oil Industry PT. Peputra Masterindo in Tanggerang Regency. Graduate Thesis. Dipenogoro University, Semarang. 2006. (Analisa Pencemaran Air Sungai Tapung Kiri oleh Limbah Industri Kelapa Sawit PT. Peputra Masterindo di Tanggerang).

[15] Hendrawan, Diana. Water Quality of Ciliwung River Based on the Oil and grease Parameter. Journal of Waters and Fisheries Sciences Indonesia, Vol. 15, Issue 2, 2008, pp. 85-93. (Kualitas Air Sungai Ciliwung Ditinjau dari Parameter Minyak dan Lemak, Jurnal Ilmuilmu Perairan dan Perikanan Indonesia).
[16] Metcalf, and Eddy. Wastewater Engineering. Treatment, Disposal, and Reuse. $3^{\text {rd }}$ Edition. Mc Graw Hill International, New York. 1991.

[17] Yudo, Satmoko, and Nusa Idaman Said. (2018). The Status of Water Quality of Ciliwung River in DKI Jakarta Region. Journal of Environmental Technology, Vol. 19, Issue 1, 2018, pp. 13-22. (Status Kualitas Air Sungai Ciliwung di Wilayah DKI Jakarta. Jurnal Teknologi Lingkungan).

[18] Markley, K.S. Fatty Acid. Their Chemistry, Properties, Production, and Uses. Interscience Publishers, Inc, New York. 1960.

[19] Ketaren, S. Dietary Fats and Oils. UI Press. 1986. (Minyak dan Lemak Pangan).

[20] Hardiana S. Setyani, and Aris Mukimin. Development of Oil and Grease Analysis in Water Sample. The Center of Industrial Pollution Prevention Technology. Semarang. 2014. (Pengembangan Metode Analisis Parameter Minyak dan Lemak pada Contoh Uji Air).

[21] Pohan, D.A. Saleh, Budiyono, and Syafrudin. Analysis of Water Quality to Determine the Designation of River Water Based on the Environmental Aspects. Journal of Environmental Sciences, Vol. 14, Issue 2, 2016, pp. 63-71. (Analisis Kualitas Air Sungai Guna Menentukan Peruntukan Ditinjau Dari Aspek Lingkungan, Jurnal Ilmu Lingkungan).

[22] Sujati, A.B., Agus Priyono, and Siti Badriyah. Characteristics of Water Quality of Ciliwung River in the Area of Bogor Botanical Garden. Media of Conservation, Vol. 22, Issue 2, 2017, pp. 111-117. (Karakteristik Kualitas Air Sungai Ciliwung di Segmen Kebun Raya Bogor. Media Konservasi).

Copyright (C Int. J. of GEOMATE. All rights reserved, including the making of copies unless permission is obtained from the copyright proprietors. 